\title{
Validating an evaluation school functionality tool
}

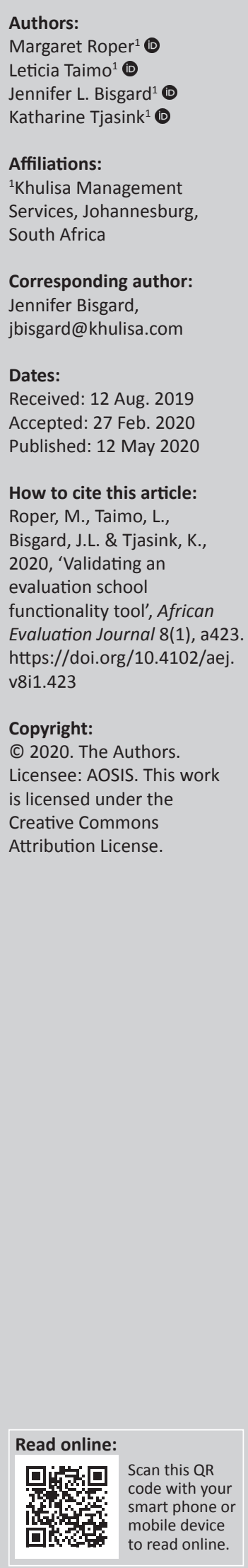

Background: Evaluators are cognisant of the need to determine the effects of an intervention within its context.

Objectives: In education evaluations, there was a gap in context-specific assessment tools to determine the status of school functionality with the ultimate aim of examining whether there is a relationship between school functionality context and teaching and learning outcomes. To meet evaluation standards, evaluators must ensure that evaluation tools and data are accurately measuring the indicators and variables. The focus of the article is on lessons learned from a tool validation process. These are shared to guide evaluators in similar settings.

Method: Khulisa Management Services (Khulisa) has conducted research and evaluations in South African schools since 1993. In 2011, Khulisa developed a school functionality tool based on local and international literature, engagement with key stakeholders, and through a series of implementation phases over various evaluations. The tool identifies high functional, functional, stagnant but functional and dysfunctional schools. The authors of this article undertook a reflection process to evaluate the evidence gathered to support the meaningfulness, usefulness and appropriateness of the tool properties.

Results: Lessons from the validation process include the need to build time and resources for validation from the beginning, validating a tool over time and across evaluations adds value, training of data collectors is critical, and analysis is important towards establishing the consistency and reliability of a tool.

Conclusion: While reliability analysis and the validation process are ongoing, preliminary results show that the tool has potential to document context appropriately.

Keywords: School; Functionality; Tool; Validation; Lessons.

\section{Introduction}

The literature on school improvement suggests that interventions are more likely to succeed when they are implemented in schools with a certain basic level of functionality. If education is to achieve educational outcomes, improve learners' well-being and breadth of skills (including socio-emotional skills) for the 21st century, then attention must be placed not only on access to schooling but also on quality of education. The question is: How do we ensure that interventions in education are achieving both quality and educational outcomes, and how do we measure the relationship between quality and educational outcomes?

Taylor and Prinsloo (2005) argue for creative and innovative ways of addressing the challenges facing the education system globally, with a focus on new school performance indicators rather than relying on pass rates. These indicators include, for example, enrolment, governance, management, leadership and teaching. Furthermore, they argue for a systemic approach to school interventions. Harris et al. (2006) postulate that interventions aimed at dysfunctional schools need to take into consideration both the external environment and the internal environment of the school itself.

As evaluators, we are cognisant of the need to determine the effect of an intervention within its context. Therefore, determining school functionality, and more specifically what and how elements of school functionality influence project/programme outcomes, is critical. There are international tools used to determine school functionality. For example, the School Function Assessment (Coster et al. 1998; Watson \& Steege 2003), which focuses on learner functional behaviour. However, there is no tool that meets local needs and is appropriate to African contexts, and which focuses on the functionality of the school rather than the learner. 
Khulisa Management Services (Khulisa) have conducted research and evaluations in South African schools since 1993. The authors hypothesised that school functionality influences learner outcomes. This hypothesis was based on the review of international research, as well as a 'gut feel' that this is particularly relevant in the context of poverty, social exclusion and resource constraints in South Africa. However, there was a gap in assessment tools to determine the status of school functionality with the ultimate aim of examining whether there is a relationship between school functionality and learning outcomes. Consequently, there was a need to develop an assessment tool.

Whether evaluators adapt a tool or design an evaluation tool, one of the key challenges is how to validate these tools, ensure that they are context-specific and they meet quality standards. To meet evaluation quality standards, evaluators must ensure that evaluation tools and data are accurately measuring the indicators and variables that they purport to measure. The principles include, amongst others:

- Validity to confirm that what is set out to be measured is measured and to what extent the measurement represents the reality it claims to represent.

- Reliability to determine the extent to which the measurement tools, analysis or specification (variable) is consistent and dependable.

- Relevance of information to meet the requirements and scope of the evaluation and the organisation or programme, and the extent to which the information answers the question, indicator or objective.

- Ethics to protect and respect the rights of beneficiaries and participants and to ensure that the choices about what is right and wrong in relation to values and behaviours are based on ethical principles.

- Equitable, fair, impartial, unbiased and without discrimination related to both the assessment tool and participation of individuals.

To meet these standards in evaluation practice, we, as evaluators, need to have tools and instruments that provide accurate data. This article focuses on the process Khulisa undertook to develop a school functionality tool. The process included an assessment of the evidence gathered to support the meaningfulness, usefulness and appropriateness of the tool properties (Chan 2014). Lessons learned from the process are shared with the aim to guide evaluators undergoing similar processes to gather quality evidence in evaluations. The tool validity and reliability scores and results are not presented in this article, as this is ongoing; rather the focus is on lessons learned from the process of validation to date.

\section{Research method and design}

Over several different evaluations focusing on learner outcomes, Khulisa developed a school functionality tool. The tool was developed based on a review of international and South African literature, engagement with key stakeholders in the education sector in South Africa and through a series of implementation phases across various geographic sites during evaluations conducted since 2011.

The tool included quantitative and qualitative indicators in several pillars (or characteristics) of schools that work, which include teaching and curriculum delivery, learning outcomes, contextual environment, resources, administration, governance, community and professional development.

Khulisa's school functionality tool used a weighted scoring mechanism of assigning 0-4 points for indicators of primary school functionality, which are combined to calculate an overall school functionality rating. The tool allows for distinguishing between four general types of schools, namely, (1) highly functional schools, (2) functional schools, (3) stagnant but functional schools and (4) dysfunctional schools.

The tool originally started out as a 1-day exercise, but over time has evolved into a rapid assessment tool to be executed by a trained evaluator or field researcher, thereby minimising disruption to teaching and learning practice as well as school management. It relies mostly on observations, with evaluators rating what they observe against a set of valuing criteria. For corroboration purposes, the tool includes a collection of photographs of certain elements of school functionality, such as the condition of the school toilets, kitchen, and periphery (e.g. outdoor space and school fences). Initially, the tool was administered using MS Excel, and photographs were taken separately. More recently, the tool was administered using mobile data collection software such as Open Data Kit (ODK) and Tangerine ${ }^{\circledR}$, which allow for real-time data collection using cellphones and tablets.

The administrative guide details procedures and considerations to ensure that ethical principles are upheld. This includes ensuring informed consent from the principal and school management and that photographs do not include children's identifiable features, such as their faces.

A systemic reflection and evaluation process was undertaken by Khulisa in 2019 to document the steps undertaken to design and validate the tool, and to extract lessons to guide future validation processes.

\section{Ethical considerations}

This article followed all ethical standards for a research without direct contact with human or animal subjects.

\section{Results}

\section{The process of designing, refining and validating the school functionality tool}

For the past 8 years, Khulisa has been in the process of refining and validating the school functionality tool. Reflection on the process indicates that the four phases as 
TABLE 1: Foundation phase school functionality (2018).

\begin{tabular}{|c|c|c|c|c|c|c|c|c|}
\hline$\#$ & Response options & Option 1 & Option 2 & Option 3 & Option 4 & Can't rate & Evidence & Instructions \\
\hline & Score & 1 & 0.5 & 0.25 & 0 & NA & & \\
\hline A & $\begin{array}{l}\text { Section A: Food and } \\
\text { nutrition }\end{array}$ & & & & & & & \\
\hline A1 & $\begin{array}{l}\text { Do the children receive } \\
\text { food at the school? }\end{array}$ & Yes & & & No & Can't rate & $\begin{array}{l}\text { Ask + } \\
\text { observe }\end{array}$ & \\
\hline A2 & $\begin{array}{l}\text { Which grades receive } \\
\text { food? }\end{array}$ & Grade R & Grade 1 & Grade 2 & Grade 3 & Grade 4 & Ask & $\begin{array}{l}\text { Select all that } \\
\text { apply (note } \\
\text { change in } \\
\text { rating to be } \\
\text { made on ODK) }\end{array}$ \\
\hline A3 & $\begin{array}{l}\text { Which meals are } \\
\text { provided to the learners? }\end{array}$ & Breakfast & $\begin{array}{l}\text { Mid-morning } \\
\text { snack }\end{array}$ & Lunch & After-school snack & Can't rate & & $\begin{array}{l}\text { Select all that } \\
\text { apply. New } \\
\text { rating for ODK }\end{array}$ \\
\hline A4 & $\begin{array}{l}\text { Is there a food garden at } \\
\text { the school? }\end{array}$ & $\begin{array}{l}\text { Yes, the food } \\
\text { garden is well } \\
\text { established }\end{array}$ & $\begin{array}{l}\text { Yes, but the } \\
\text { garden was } \\
\text { recently started }\end{array}$ & $\begin{array}{l}\text { Yes, but the } \\
\text { garden is not well } \\
\text { maintained }\end{array}$ & No & $\begin{array}{l}\text { Can't rate } \\
\text { because of } \\
\text { being locked }\end{array}$ & Observe & \\
\hline A5 & $\begin{array}{l}\text { Which food groups are } \\
\text { provided? }\end{array}$ & $\begin{array}{l}\text { Carbohydrates } \\
\text { that is pap, } \\
\text { samp, rice, } \\
\text { potatoes }\end{array}$ & Fruits & Vegetables & $\begin{array}{l}\text { Proteins that is } \\
\text { beans, chicken, } \\
\text { fish, meat }\end{array}$ & $\begin{array}{l}\text { Can't rate } \\
\text { because of } \\
\text { being locked }\end{array}$ & Observe & $\begin{array}{l}\text { Select all that } \\
\text { apply (note } \\
\text { change in } \\
\text { rating to be } \\
\text { made on ODK) }\end{array}$ \\
\hline A6 & $\begin{array}{l}\text { Is the food preparation } \\
\text { area open and available } \\
\text { for observation? }\end{array}$ & $\begin{array}{l}\text { Excellent - } \\
\text { indoors, } \\
\text { enough space } \\
\text { for food } \\
\text { handlers to } \\
\text { work }\end{array}$ & $\begin{array}{l}\text { Good-indoors } \\
\text { lack of space to } \\
\text { work }\end{array}$ & Poor-roof only & $\begin{array}{l}\text { Very poor- } \\
\text { outside in the } \\
\text { open }\end{array}$ & $\begin{array}{l}\text { Can't rate } \\
\text { because of } \\
\text { being locked }\end{array}$ & Observe & \\
\hline A7 & $\begin{array}{l}\text { Is the food preparation } \\
\text { area clean? }\end{array}$ & Very clean & Mostly clean & Mostly unclean & Very unclean & $\begin{array}{l}\text { Can't rate } \\
\text { because of } \\
\text { being locked }\end{array}$ & Observe & \\
\hline A8 & $\begin{array}{l}\text { Please take a photo of } \\
\text { the school preparation } \\
\text { area }\end{array}$ & & & & & & Photo & \\
\hline B & $\begin{array}{l}\text { Section B: Hygiene and } \\
\text { healthcare }\end{array}$ & & & & & & & \\
\hline B1 & $\begin{array}{l}\text { Which of the following } \\
\text { sanitation facilities does } \\
\text { the centre/school have } \\
\text { for learners? Select one }\end{array}$ & Flush toilets & $\begin{array}{l}\text { Waterless } \\
\text { toilets, for } \\
\text { example, VIP, } \\
\text { urine diversion } \\
\text { toilet, etc. }\end{array}$ & $\begin{array}{l}\text { Pit latrines, bucket } \\
\text { systems, potties }\end{array}$ & None & Can't rate & Observe & \\
\hline B3 & $\begin{array}{l}\text { Please take a photo of } \\
\text { the school's sanitation } \\
\text { facilities (toilets, pit } \\
\text { latrines, bucket systems, } \\
\text { potties, etc.) }\end{array}$ & & & & & & Photo & \\
\hline B4 & $\begin{array}{l}\text { Are the learners' } \\
\text { sanitation facilities clean? }\end{array}$ & Yes & $\begin{array}{l}\text { Moderately } \\
\text { clean - can } \\
\text { improve }\end{array}$ & & No & $\begin{array}{l}\text { Can't rate } \\
\text { because of } \\
\text { being locked }\end{array}$ & Observe & \\
\hline B5 & $\begin{array}{l}\text { Are these sanitation } \\
\text { facilities safe? }\end{array}$ & Yes & $\begin{array}{l}\text { Moderately safe } \\
\text { - can improve }\end{array}$ & & No & $\begin{array}{l}\text { Can't rate } \\
\text { because of } \\
\text { being locked }\end{array}$ & Observe & \\
\hline B6 & $\begin{array}{l}\text { Are there hand washing } \\
\text { facilities? }\end{array}$ & Yes & & & No & Can't rate & Observe & \\
\hline B7 & $\begin{array}{l}\text { If yes, are the hand } \\
\text { washing facilities clean? }\end{array}$ & & $\begin{array}{l}\text { Moderately } \\
\text { clean - can } \\
\text { improve }\end{array}$ & & & $\begin{array}{l}\text { Can't rate } \\
\text { because of } \\
\text { being locked }\end{array}$ & Observe & \\
\hline B8 & $\begin{array}{l}\text { Is drinking water } \\
\text { provided? }\end{array}$ & $\begin{array}{l}\text { Yes - water } \\
\text { fountain or tap } \\
\text { water available }\end{array}$ & $\begin{array}{l}\text { Yes - water } \\
\text { buckets and } \\
\text { cups }\end{array}$ & $\begin{array}{l}\text { Water available } \\
\text { from river or other } \\
\text { natural source }\end{array}$ & $\begin{array}{l}\text { No drinking water } \\
\text { available }\end{array}$ & Can't rate & Observe & \\
\hline C & $\begin{array}{l}\text { Section C: School } \\
\text { environment }\end{array}$ & & & & & & & \\
\hline C.1 & $\begin{array}{l}\text { Is the school periphery } \\
\text { secured? }\end{array}$ & $\begin{array}{l}\text { Periphery } \\
\text { secure, security } \\
\text { working well, } \\
\text { for example, } \\
\text { gate access is } \\
\text { controlled; } \\
\text { security fence } \\
\text { secure }\end{array}$ & $\begin{array}{l}\text { Reasonable, but } \\
\text { some systems } \\
\text { breaking down } \\
\text { (e.g. lack of } \\
\text { access control } \\
\text { and broken } \\
\text { walls) }\end{array}$ & $\begin{array}{l}\text { Clear efforts being } \\
\text { made to secure } \\
\text { learners' and } \\
\text { educators' safety, } \\
\text { but a lack of } \\
\text { resources to do } \\
\text { so properly (e.g. } \\
\text { fence broken and } \\
\text { no security access) }\end{array}$ & $\begin{array}{l}\text { Security is a } \\
\text { problem that } \\
\text { constantly arises } \\
\text { and evidence of } \\
\text { breaching is } \\
\text { readily apparent }\end{array}$ & & Observe & \\
\hline
\end{tabular}


TABLE 1 (Continues...): Foundation phase school functionality (2018).

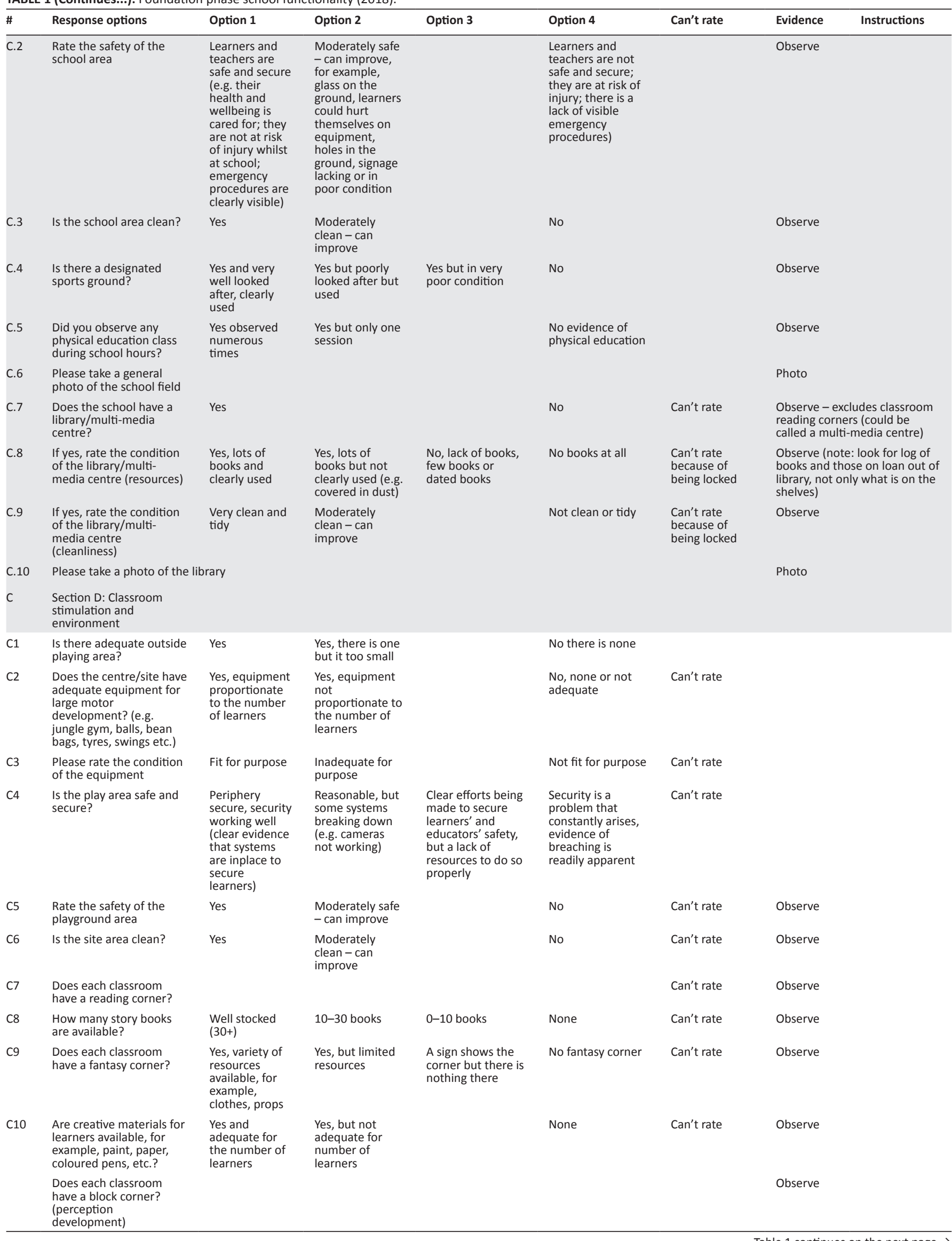


TABLE 1 (Continues...): Foundation phase school functionality (2018).

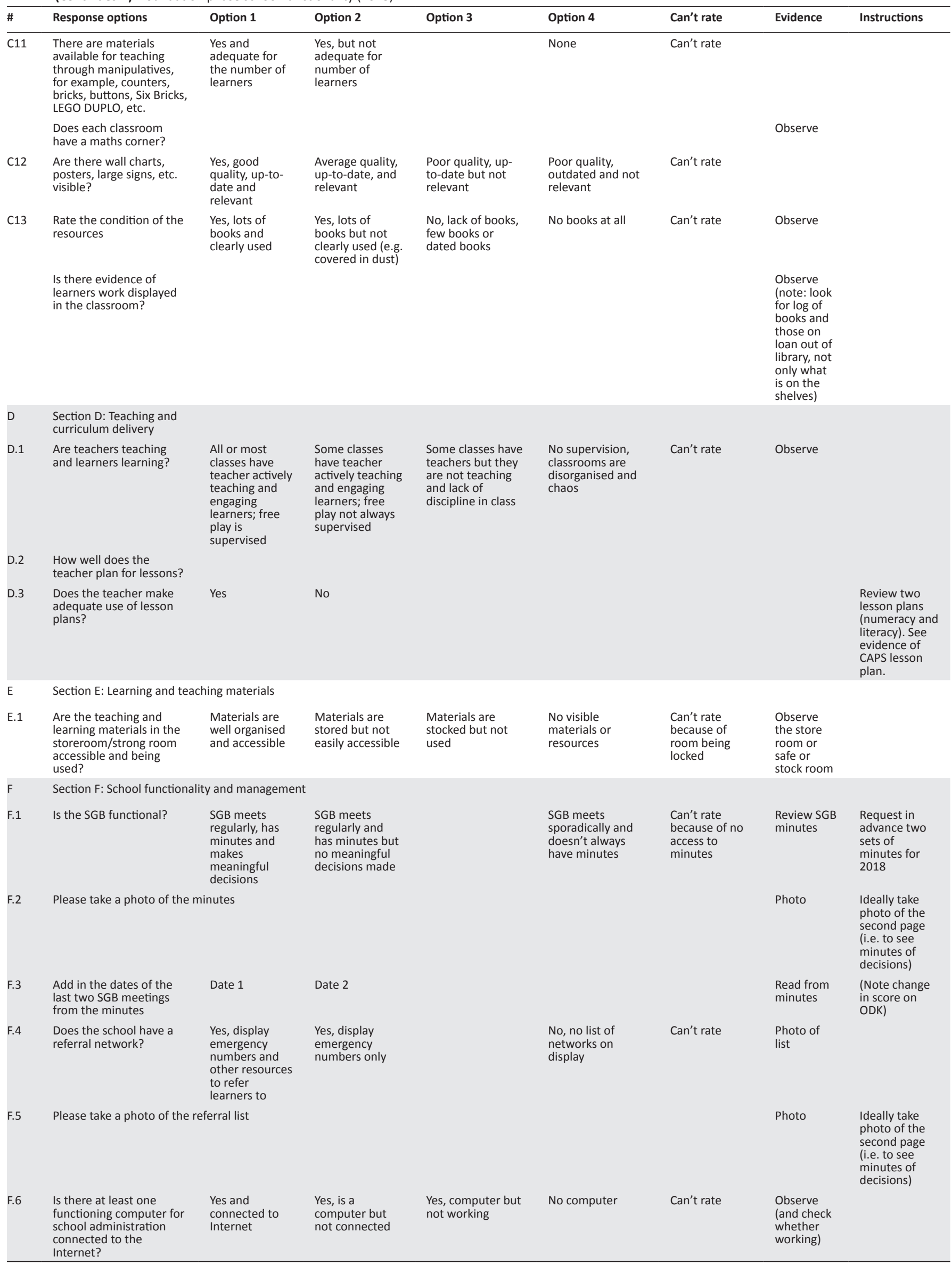


TABLE 1 (Continues...): Foundation phase school functionality (2018).

\begin{tabular}{|c|c|c|c|c|c|c|c|c|}
\hline$\#$ & Response options & Option 1 & Option 2 & Option 3 & Option 4 & Can't rate & Evidence & Instructions \\
\hline G & \multicolumn{8}{|c|}{ Section G: School rating of functionality } \\
\hline G.1 & $\begin{array}{l}\text { How does this school } \\
\text { compare to other schools } \\
\text { in the (province)? }\end{array}$ & $\begin{array}{l}\text { Above standard } \\
\text { (atmosphere at } \\
\text { school } \\
\text { supports } \\
\text { learning; } \\
\text { culture of } \\
\text { teaching; } \\
\text { principal is } \\
\text { proud of the } \\
\text { school, etc.) }\end{array}$ & $\begin{array}{l}\text { Average } \\
\text { (teaching and } \\
\text { learning is } \\
\text { happening; basic } \\
\text { school } \\
\text { management is } \\
\text { in place) }\end{array}$ & & $\begin{array}{l}\text { Below standard } \\
\text { (learning and } \\
\text { teaching is not } \\
\text { happening; school } \\
\text { is not being } \\
\text { managed) }\end{array}$ & & $\begin{array}{l}\text { Own view } \\
\text { (note } \\
\text { reason on } \\
\text { fieldwork } \\
\text { review } \\
\text { report) }\end{array}$ & $\begin{array}{l}\text { (Not verified } \\
\text { variable) }\end{array}$ \\
\hline G.2 & $\begin{array}{l}\text { Would I send my child to } \\
\text { this school? }\end{array}$ & $\begin{array}{l}\text { I would happily } \\
\text { send my own } \\
\text { child to this } \\
\text { school }\end{array}$ & $\begin{array}{l}\text { It once was a } \\
\text { school that I } \\
\text { would have } \\
\text { considered for } \\
\text { my child but it is } \\
\text { deteriorating }\end{array}$ & $\begin{array}{l}\text { The school is } \\
\text { working but I } \\
\text { would not send } \\
\text { my own child to } \\
\text { this school }\end{array}$ & $\begin{array}{l}\text { The department } \\
\text { needs to take } \\
\text { immediate action } \\
\text { to fix this school }\end{array}$ & & $\begin{array}{l}\text { Own view } \\
\text { (note } \\
\text { reason on } \\
\text { fieldwork } \\
\text { review } \\
\text { report) }\end{array}$ & $\begin{array}{l}\text { (Not verified } \\
\text { variable) }\end{array}$ \\
\hline H & \multicolumn{6}{|c|}{ Please add anything you would like to note about this school } & $\begin{array}{l}\text { Based on } \\
\text { observation }\end{array}$ & Text response \\
\hline 1.2 & \multicolumn{6}{|c|}{ Photo 2: Please take a photo of anything you find interesting } & Photo & \\
\hline
\end{tabular}

ODK, open data kit; SGB, school governing body.

identified by Creswell (2012) were followed. These phases are:

1. planning

2. construction

3. quantitative evaluation

4. validation.

This section (Table 1) reflects on our experience and describes the process undertaken under each phase.

\section{Planning}

This phase includes, firstly, identifying the purpose of the tool, the content area and who the relevant stakeholders are; secondly, reviewing the literature to check existence of similar tools and to determine definitions of the variables and constructs to be measured and lastly developing open-ended questions to present and engage with relevant stakeholders. The results of these elements should inform the development of the tool scope and components.

For Khulisa, the opportunity to develop the tool emerged in 2011 as we were contracted by a Foundation to conduct a 6-year evaluation of a range of projects implemented in 60 schools across the country. Our proposal included going into the schools before they received the projects' interventions to ascertain their level of functionality. Significant effort was expended to design a school functionality data collection tool that could be administered with verifiable data.

Our evaluation team conducted an extensive review of international and South African literature on school functionality to determine the variables and constructs to be measured. Together with the funder, Khulisa identified relevant stakeholders with which to engage and to support the development of the tool. Finally, Khulisa consulted with an education Foundation, consulted with academics from four South African universities and education experts. This led to the development of several indicators and the various school functionality pillars. This planning phase also occurred iteratively in future evaluations, where we had to update the literature with more recent findings from research.

\section{Construction}

This phase is about developing the tool. The first step is to identify the tool's objectives and develop a table of specifications whereby each indicator is linked to a concept and overall theme (Statistics Solutions 2018). Upon completion, it is time to build the tool, which includes looking at question format (e.g. multiple choice, nominal scales, ordinal, Likert scale, etc.) based on the type of data required for each question and/or indicator. When developing the tool, other sector/area specialists can be involved in the development process and to review the tool.

Once the tool is built and reviewed, it is presented to peers and other stakeholders to match items to specifications - and if there is not a direct match then it needs to be reviewed. The contents of a tool are considered valid when the indicators adequately reflect the various dimensions of the objective of the tool (Benson \& Clark 1982). In the end, the tool is finally reviewed by relevant stakeholders who critique the quality of individual items and the tool as a whole (Statistics Solutions 2018).

In developing the school functionality tool (Figure 1), we workshopped the design, content and indicators collaboratively with relevant stakeholders. This included local Foundations working in education, academics and the South African Department of Basic Education. This exercise was important to establish buy-in and obtain input into the indicators we had developed based on the literature and engagements in the initial phase discussed above.

The initial development of the tool did not include schoollevel input, as it was not part of the evaluation design. However, the evidence to support the tool development came from academics and education officials who engaged 


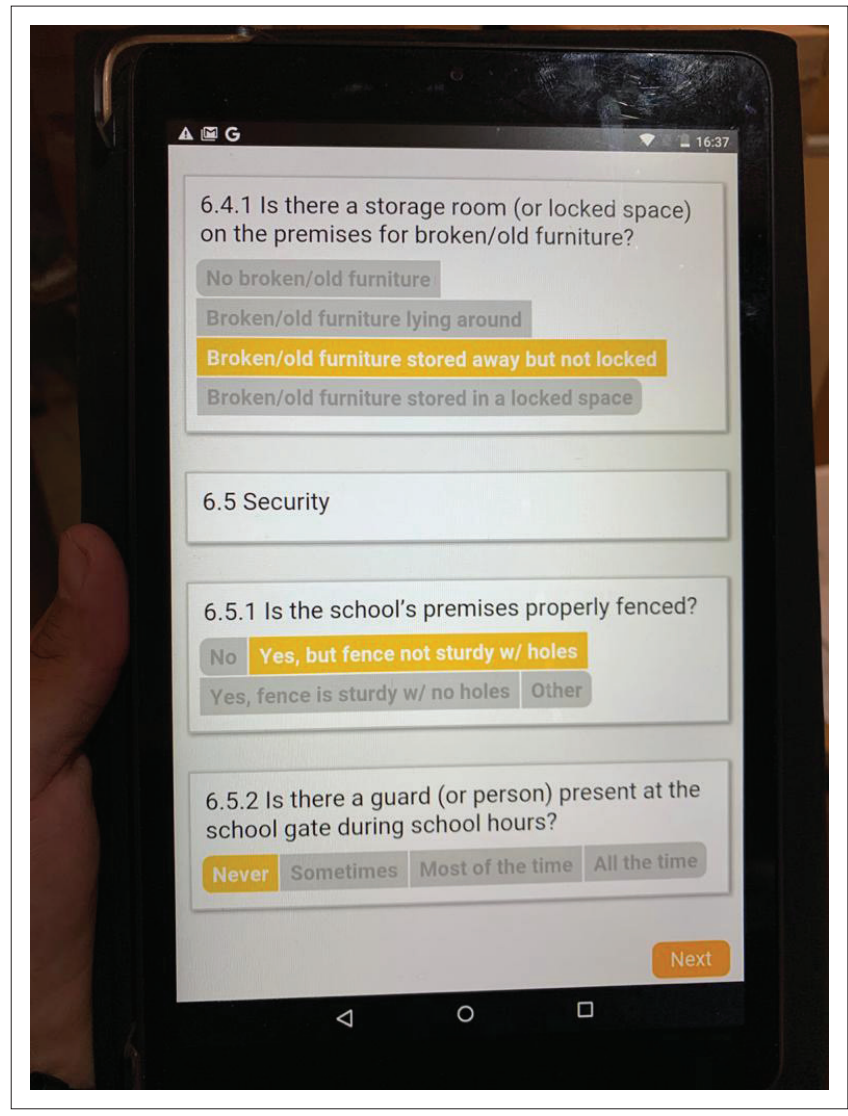

FIGURE 1: School functionality tool.

directly with the realities of school management and functionality. At this stage, tool validation was not the primary intention. The value of the process was that it garnered evidence and insights from a select group that subsequently informed a pilot test of the tool. Tool construction was not a once-off process, as we held workshops every time we revised and adapted the tool for use in our evaluations, thus at each round getting further input, refining the items and ensuring items directly matched the relevant variables. The image below provides a snapshot of some of the questions included in a recent iteration of the tool.

In a later evaluation, we developed a table of specifications (Table A1), which included reference to the literature, government norms and standards, scales of measurement and criteria for standards.

\section{Quantitative evaluation (and current results)}

This phase involves pre-testing or 'first pilot' of the tool with a representative sample and collecting feedback on the tool. For example, this may include asking questions such as 'Is the tool being administered in the estimated time?', 'Is the tool too long?', 'Are the tool questions clear?', 'Are questions formatted appropriately?'

In addition to the feedback collected, it is important to analyse the data collected to check for internal consistency. This step checks the correlation between questions measuring the same variable. A standard test of internal consistency is Cronbach's
TABLE 2: Piloting of the school functionality tool.

\begin{tabular}{llc}
\hline Year & Provinces of South Africa & Number of sites $\dagger$ \\
\hline $2011 / 2012$ & Gauteng, Eastern Cape and Western Cape & 63 \\
2012 & KwaZulu-Natal & 20 \\
2013 & Free State & 20 \\
2017 & Free State and KwaZulu-Natal & 37 \\
$2017-2018$ & All nine provinces of South Africa & $593 \dagger$ \\
2019 & North West Province & 229 \\
\hline Total sites & & 962 \\
\hline
\end{tabular}

$\dagger$, Includes 209 early childhood development centres.

alpha (or coefficient alpha), whereby values of 0.70 or higher indicate acceptable reliability (George \& Mallery 2003; Statistics Solutions 2018). These measurements can assist in revising a tool based on evidence, rather than just a 'gut feel'.

In this phase, as with all our instruments, we pre-tested or 'piloted' the school functionality tool. Firstly, to receive feedback on the length, language and clarity of the tool. Secondly, to adapt and refine the tool to ensure relevance to the South African context and to determine consistency of measures and responses.

Khulisa used the tool in several different evaluations over the years to inform the piloting process. The tool was tested and refined over a series of pilots carried out during six evaluations where the tool was tested in a total of 962 sites (including schools and early childhood development centres), as illustrated in Table 2.

Edits to the tool, following feedback, included:

- The initial tool included learner outcomes as measured by the Annual National Assessments (ANAs). However, when the ANAs were discontinued by the Department of Basic Education (DBE) in 2015, these data were not available. Consequently, this indicator was removed from the 2017 version of the tool. Then in 2019, the tool was revised to include an indicator of learner literacy outcomes, as it was a requirement of the evaluation being conducted at the time. These data were obtained through primary data collection. ${ }^{1}$

- Initially, the tool took a full day to be administered. The feedback was that the tool could not be administrated easily within the given timeframe. The tool was subsequently revised to allow the evaluator to observe the different indicators during a school day across different settings (e.g. kitchen, safety of school, etc.), and enter the ratings into the tool following each point of observation. This was a more efficient use of the evaluator/researcher's time, improving the costeffectiveness of the evaluation without comprising quality.

- Initially, the tool was administered using paper and pencil, and the data entered into a laptop. The feedback was that this was time-consuming, cumbersome and led to errors in data entry. With the development of rigorous 1.The evaluation findings are not currently available for public release. 
open-source mobile data collection platforms, we began to implement the tool using mobile data collection applications. This meant that the tool could be easily administered in real-time, which avoided duplicate entries, was less time-consuming and improved management of the data. For example, it allowed instant access to the data for daily quality checks, improved fieldworker management and ultimately improved data quality. Furthermore, mobile data collection improved the ability of the evaluation team to verify observations and ratings through the use of photographs and global positioning system (GPS) locations.

Importantly, as the tool required observations, providing adequate training (for inter-rater reliability), and having a method to moderate responses, was critical, hence the use of photographs and the inclusion of supervisors in the field.

Originally, the tool was designed to provide a rating of school functionality. The ratings were qualitatively confirmed across several evaluations and through peer review by experts in the field, evaluators, clients and government officials.

The premise behind school functionality is that dysfunctional schools lack the leadership, management and other skills needed to run a school effectively and that efforts to improve teaching and learning will not have an effect as teachers are not teaching and learners tend not to be learning. At the other end of the spectrum, highly functional schools do not require programme intervention. In the middle, there are functional schools, often with entrepreneurial principals who gather resources from lots of sources and then use them, that would benefit from programme support. The international literature does not discuss 'stagnant schools'. This category was added by Khulisa when collecting data to describe schools that once were either functional or highly functional but now are operating on legacy good practices and resources.

It is only as we have moved into the full validation phase that we are beginning a process of quantitatively evaluating the reliability and validity of the tool (discussed below).

\section{Validation}

This final step involves quantitatively establishing validity through a final round of testing the tool and reviewing the data against criteria. Here, it is important to understand the different constructs of validity and the relevance of each to the purpose of an evaluation in a specific context.

- Content validation determines the extent to which the items on a tool represent the domains or constructs that the tool intends to measure. At least three experts should be consulted (Statistics Solutions 2018).

- Criterion-related validation determines if a tool is a good predictor of an expected outcome that it is theoretically expected to predict. Here, a correlation coefficient of over 0.60 indicates a significant positive relationship (Creswell 2012; Statistics Solutions 2018).
- Construct validation determines how well a test or experiment measures up to its claims that is if the score recorded by a tool is meaningful, significant, useful and has a purpose. It achieves this by comparing the relationship of a question from the scale to the overall scale, testing a theory to determine if the outcome supports the theory and by correlating the scores with other similar or dissimilar variables (Statistics Solutions 2018).

Either one or all of these types of validity may be conducted. The decision is based on what the tool will be used for and the strength of validity required.

Given the iterative nature of the school functionality tool, the fact that it has been reviewed by academics, experts and government officials, and it aligns with literature, government norms and standards, provides scales of measurement and has set criteria for standards, Khulisa believes that the content validity of the tool has been adequately established (although it would benefit further from a review from school officials, which Khulisa will undertake as part of a subsequent application of the tool).

Khulisa has begun a construct and criterion-related tool validation process using data from a recent evaluation, which looked at the impact of three reading interventions on learner reading outcomes. In this evaluation, a team of researchers administered an adapted version of the school functionality tool to 229 schools in one province in South Africa. The tool was administered alongside other evaluation tools including learner reading assessments, teacher and principal questionnaires, classroom observations and a parent questionnaire.

The school functionality tool administered in this evaluation collected information on various domains, including the status of food and nutrition, hygiene and healthcare, the school environment, teaching and curriculum delivery, learning and teaching materials and school management. As it relied mostly on observations, the tool by its nature reflected the judgements of the trained researcher, where each researcher's response was influenced by his or her own frame of reference (albeit informed by rigorous training) as to acceptable quality standards. For verification purposes, fieldworkers took photographs of certain elements. The researchers intend to explore whether school functionality status potentially affects the effectiveness of the reading interventions in schools, and therefore have an effect on learner reading performance.

\section{Discussion}

The following key lessons emerge from our experience developing, refining and starting the process of validating the school functionality tool. The lessons below provide guidance to evaluators embarking on a tool validation process. 
Firstly, it is important that there is sufficient time to develop, test and refine the tool. Assuming it is not possible to build the full process into one evaluation, because of cost and time limitations, building a tool over time and over a range of existing and relevant projects (where possible) can provide useful insights. There is a reciprocal advantage in that budgets from various evaluations can contribute to the development of a tool that can be used by a wider audience and, on the contrary, evaluation commissioners benefit from building on an established tool rather than starting over. Disadvantages include having to adapt the tool to serve the interests of different stakeholder groups and to suit the needs of different evaluations.

Secondly, it is critical to build in time and resources for a validation process from the beginning. Looking retrospectively at our process, establishing content validity required several rounds of reviews and pre-tests, and iterative tool refinement, to come to a point where the tool encompassed the correct constructs in line with the literature, government norms and standards, and with contextually appropriate scales of measurement and set criteria for standards. When designing or adapting a tool to context, it is advisable to plan for reliability and validation from the start. The process requires many team members with different skill-sets and technical specialists (in our case, tool development specialists, statisticians and education specialists) to assist in the process.

Thirdly, rigorous training of researchers is imperative. As previously explained, the tool relies mostly on observations, which are biased to the observer's frame of reference. Thus, it is important to establish that different researchers are collecting data in a consistent way. This involves rigorously training for the researchers and checking for inter-rater reliability. It typically involves a 3-day training process, where the first day consists of familiarisation with the tool and training on the ethics of collecting data in schools (including photographing children), the second day involves experiential learning where researchers collect real data on site and the third day includes feedback to researchers and revisions (if required) to the tool.

Finally, we learned that including sources of verification, in our case the option for photographs to be taken, was a key element to ensure consistency of scoring. For example, by examining photographs taken of the toilets, one can determine whether researchers are rating these in the same way. If this is not the case, there is a need to explore why not (e.g. do the researchers require more training? or, is the question or measurement criterion not clear?). Given the sensitivity of this type of data source, it is important that such data are adequately protected in line with the relevant laws and legislation.

\section{Conclusion}

Validity is an ongoing process over time (Benson \& Clark 1982; Creswell 2012), and the deeper and more rigorous the analysis and greater the range of samples, the stronger the case for validity. Khulisa has started the process of validation, with substantial evidence towards the content validity of the tool, as documented in this article. Khulisa next intends to examine the construct and criterion-related validity of the school functionality tool. We are statistically analysing the internal consistency of the items within each of the domains in the tool and intend to conduct a confirmatory factor analysis to establish the construct validity of the tool. Once validity is fully established, we will look at whether the results from the tool indicate any significant differential treatment effects on learner performance. The results of these analyses will be written up for publication in future journal articles.

\section{Acknowledgements}

The authors would like to thank the various clients who have contributed to the development and validity of this tool and in particular for the collaboration with the researchers at the South African Department of Basic Education for their valuable insights, analysis and review of the instruments.

\section{Competing interests}

The authors declare that they have no financial or personal relationships that may have inappropriately influenced them in writing this article.

\section{Authors' contributions}

All authors contributed equally to this work.

\section{Funding information}

This research received no specific grant from any funding agency in the public, commercial or not-for-profit sectors.

\section{Data availability statement}

Data sharing is not applicable to this article as no new data were created or analysed in this study.

\section{Disclaimer}

The views and opinions expressed in this article are those of the authors and do not necessarily reflect the official policy or position of any affiliated agency of the authors.

\section{References}

Benson, J. \& Clark, F., 1982, 'A guide for instrument development and validation', The American Journal of Occupational Therapy 36(12), 789-800. https://doi. org/10.5014/ajot.36.12.789

Brey, A., 2017, "The effects of "6 BRICKS" guided play on grade two learners visual perception and reasoning abilities', PhD thesis, Faculty of Education, Nelson Mandela Metropolitan University.

Chan, E.K.H., 2014, 'Chapter 2: Standards and guidelines for validation practices: Development and evaluation of measurement instruments', in B.D. Zumbo \& E.K.H. Chan (eds.), Validity and validation in social, behavioural, and health sciences, Social Indicators Research Series, vol. 54, pp. 9-24, Springer International Publishing, Cham.

Coster, W., Deevev, T., Haltiwanger, J. \& Halay, S., 1998, School functionality assessments: Psychological corporation, Pearson Clinical, San Antonio, TX. 
Creswell, J.M., 2012, Educational research: Planning, conducting, and evaluating quantitative and qualitative research, 4 th edn., Pearson Education Inc, Upper Saddle River, NJ.

Department of Basic Education (DBE), 2008, Schools that affirm excellence and challenge mediocrity: A road map for school improvement through self-evaluation, Department of Education, Pretoria.

Department of Basic Education (DBE), 2013, Regulations relating to minimum uniform norms and standards for public school infrastructure, Government Notice R920, Government Gazette 37081 of 29 November 2013, Pretoria.

Department of Social Development, May 2006, Guidelines for early childhood development services, UNICEF, Pretoria.

De Kadt, J., Norris, S.A., Fleisch, B., Richter, L. \& Alvanides, S., 2014, 'Children's daily travel to school in Johannesburg-Soweto, South Africa: Geography and school choice in the birth to twenty cohort study', Children's Geographies 12(2), 170-188. https://doi.org/10.1080/14733285.2013.812304

Ebersöhn, L., Loots, T., Eloff, I. \& Ferreira, R., 2015, 'In-service teacher training to provide psychosocial support and care in high-risk and high-need schools: School-based intervention partnerships', Journal of Education for Teaching 41(3), 267-284. https://doi.org/10.1080/02607476.2015.1044226

Gallie, M., 2008, Understand school leadership and governance in the South African context, Department of Education Republic of South Africa, Tshwane.

George, D. \& Mallery, P., 2003, SPSS for Windows step by step: A simple guide and reference, 11.0 update, Allyn Bacon, Boston, MA

Görgens-Ekermans, G., Delport, M. \& Du Preez, R., 2015, 'Developing emotional intelligence as a key psychological resource reservoir for sustained student success', SA Journal of Industrial Psychology/SA Tydskrif vir Bedryfsielkunde 41(1) Art. \#1251, 13 pages. https://doi.org/10.4102/sajip.v41i1.1251

Heneveld, W. \& Craig, H., 1996, Schools count: World Bank project designs and the quality of primary education in sub-Saharan Africa, vol. 23-303, World Bank, Washington, DC

Harris, A., Chapman, C., Muijs, D., Russ, J. \& Stoll, L., 2006, 'Improving schools in challenging contexts: Exploring the possible, school effectiveness and schoo improvement', An International Journal of Research, Policy and Practice 17(4), 409-424. https://doi.org/10.1080/09243450600743483

Hui Liu, Y. \& Stein, M., 2012, Feeding behaviour of infants and young children and its impact on child psychosocial and emotional development. Encyclopaedia on early childhood development, Centre of Excellence for Early Childhood Development and Strategic Knowledge Cluster on Early Child Development, Montreal.
Jansen, J.D. \& Blank, M., 2014, How to fix South Africa's schools: Lessons from schools that work, Bookstorm, Northcliff.

JET Education Services \& CASE, 2007, Learner absenteeism in the South African schooling system, Department of Education, Braamfontein, Johannesburg.

Khulisa, 2012, FNB evaluation report, Tshikululu Social Investments, Johannesburg.

Khulisa, 2017, FNB evaluation report, Tshikululu Social Investments, Johannesburg.

Kisoon, 2019, The right to water and sanitation: 'Leave no one behind', South African Human Rights Commission, viewed 18 March 2019, from https://www.sahrc.org. za/index.php/sahrc-media/opinion-pieces/item/1860-the-right-to-water-andsanitation-leaveno-one-behind.

Ngure, F.M., Reid, B.M., Humphrey, J.H., Mbuya, M.N., Pelto, G. \& Stolzfus, R.J., 2014, 'Water, sanitation, and hygiene (WASH), environmental enteropathy, nutrition, and early child development: Making the links', Annals of the New York Academy of Sciences 1208, 118-128. https://doi.org/10.1111/nyas.12330

Sasol Inzalo, 2009, External evaluation report, Khulisa Management Services, Johannesburg.

Spaull, N., 2012, 'Poverty and privilege: Primary school inequality in South Africa', Stellenbosch Economic Working Papers, no. 13/12, Stellenbosch.

South African Human Rights Commission, SAHRC, 2014, Report on the right to access sufficient water and decent sanitation in South Africa, viewed 28 March 2019, from https://www. sahrc.org.za/home/21/files/FINAL\%204th\%20Proof\%204\%20 March\%20-\%20 Water\%20\%20Sanitation\%20low\%20res\%20(2).pdf.

Statistics Solutions, 2018, Creating and validating an instrument, viewed 19 July 2018 , from https://www.statisicssolutions.com/creating-and-validating-an-instrument/.

Taylor, N. \& Prinsloo, C., 2005, 'The quality learning project: Lessons for high school improvement in South Africa', Presentation to the consortium for research on school quality seminar, Department of Education, Pretoria.

Taylor, S., 2011, 'Uncovering indicators of effective school management in South Africa using the National School Effectiveness Study', Stellenbosch Economic Working Papers, no. 10/11, viewed 28 March 2019, from https://resep.sun.ac.za/ wp-content/ uploads/2017/10/wp-10-2011.pdf.

UNICEF, 2012, School readiness: A conceptual framework, United Nations Children's Fund, New York, NY.

Watson, T.S. \& Steege, M.W., 2003, Conducting school-based functional behavioural assessments: A practitioner's guide, The Guilford practical intervention in the schools series, Guilford Press, New York, NY. 


\section{Appendix 1}

TABLE A1: School functionality validation matrix.

\begin{tabular}{|c|c|c|c|c|c|c|c|c|c|}
\hline $\begin{array}{l}\text { School } \\
\text { functionality } \\
\text { domain }\end{array}$ & $\begin{array}{l}\text { School } \\
\text { functionality } \\
\text { category/ } \\
\text { element }\end{array}$ & $\begin{array}{l}\text { Assessment } \\
\text { objective: } \\
\text { What is being } \\
\text { measured? }\end{array}$ & $\begin{array}{l}\text { Functionality } \\
\text { variable }\end{array}$ & $\begin{array}{l}\text { Question number } \\
\text { on school } \\
\text { functionality tool } \\
\text { (for AEJ article } \\
\text { analysis) } \$\end{array}$ & $\begin{array}{l}\text { Question to be } \\
\text { answered }\end{array}$ & $\begin{array}{l}\text { Type of } \\
\text { data / } \\
\text { question }\end{array}$ & Research & $\begin{array}{l}\text { Norms and } \\
\text { standards: } \\
\text { Public schools } \\
\text { in SA }\end{array}$ & $\begin{array}{l}\text { Norms and } \\
\text { Standards: ECD }\end{array}$ \\
\hline \multirow[t]{5}{*}{$\begin{array}{l}\text { 1. Learner } \\
\text { outcomes }\end{array}$} & \multirow[t]{5}{*}{$\begin{array}{l}\text { Achievement } \\
\text { of learner } \\
\text { outcome/s } \\
\text { (define per } \\
\text { evaluation) }\end{array}$} & \multirow[t]{2}{*}{$\begin{array}{l}\text { Early Grade } \\
\text { Reading }\end{array}$} & $\begin{array}{l}\text { Ability of learners } \\
\text { to achieve early } \\
\text { grade reading } \\
\text { benchmarks }\end{array}$ & NA & $\begin{array}{l}\text { Refer to leaner } \\
\text { assessment tool }\end{array}$ & - & $\begin{array}{l}\text { DBE (2008) } \\
\text { PIRLS Results }\end{array}$ & - & - \\
\hline & & & $\begin{array}{l}\text { Effectiveness of } \\
\text { teaching early } \\
\text { grade reading }\end{array}$ & NA & $\begin{array}{l}\text { Refer to leaner } \\
\text { assessment tool }\end{array}$ & - & - & - & - \\
\hline & & $\begin{array}{l}\text { Early Grade } \\
\text { Numeracy }\end{array}$ & - & NA & $\begin{array}{l}\text { Refer to leaner } \\
\text { assessment tool }\end{array}$ & - & TIMMS results & - & - \\
\hline & & $\begin{array}{l}\text { School } \\
\text { 'readiness' }\end{array}$ & - & NA & $\begin{array}{l}\text { Refer to leaner } \\
\text { assessment tool }\end{array}$ & - & $\begin{array}{l}\text { School } \\
\text { readiness: a } \\
\text { conceptual } \\
\text { framework, } \\
\text { UNICEF (2012) }\end{array}$ & - & - \\
\hline & & $\begin{array}{l}\text { Developmental } \\
\text { outcomes }\end{array}$ & $\begin{array}{l}\text { Visual perception, } \\
\text { executive } \\
\text { functioning, etc. }\end{array}$ & NA & $\begin{array}{l}\text { Refer to leaner } \\
\text { assessment tool/s } \\
\text { (where exist) }\end{array}$ & - & $\begin{array}{l}\text { Dr Amina Brey } \\
\text { (2017) }\end{array}$ & - & - \\
\hline \multirow[t]{10}{*}{$\begin{array}{l}\text { 2. Teaching } \\
\text { and } \\
\text { curriculum } \\
\text { delivery }\end{array}$} & \multirow[t]{3}{*}{$\begin{array}{l}\text { Teaching of } \\
\text { the } \\
\text { curriculum }\end{array}$} & \multirow[t]{8}{*}{$\begin{array}{l}\text { Teaching and } \\
\text { learning is } \\
\text { delivered } \\
\text { according to } \\
\text { the curriculum }\end{array}$} & \multirow{2}{*}{$\begin{array}{l}\text { Teaching practice } \\
\text { is aligned to the } \\
\text { curriculum, } \\
\text { curriculum } \\
\text { planner, CAPS } \\
\text { and workbooks }\end{array}$} & $\begin{array}{l}\text { Relevant if grade } \\
\text { specific } \$\end{array}$ & $\begin{array}{l}\text { How many } \\
\text { curriculum/ } \\
\text { programme weeks } \\
\text { in the current year? }\end{array}$ & Number & \multirow{10}{*}{$\begin{array}{l}\text { DBE (2008) } \\
\text { Heneveld and } \\
\text { Craig (1996) } \\
\text { Gallie (2008) } \\
\text { Sasol Inzalo } \\
\text { (2009) JET } \\
\text { Education } \\
\text { Services \& CASE } \\
\text { (2007) Khulisa } \\
\text { (2012) Jansen \& } \\
\text { Molly (2014) }\end{array}$} & \multirow[t]{10}{*}{$\begin{array}{l}\text { Refer to } \\
\text { relevant } \\
\text { curriculum } \\
\text { statements }\end{array}$} & \multirow[t]{10}{*}{-} \\
\hline & & & & $\begin{array}{l}\text { Relevant if grade } \\
\text { specific }\end{array}$ & $\begin{array}{l}\text { What week of the } \\
\text { curriculum/ } \\
\text { programme are you } \\
\text { currently in? }\end{array}$ & Number & & & \\
\hline & & & $\begin{array}{l}\text { Teachers actively } \\
\text { teaching }\end{array}$ & Q4.1 & $\begin{array}{l}\text { Are teachers } \\
\text { teaching and } \\
\text { learners learning? }\end{array}$ & $\begin{array}{l}\text { Open- } \\
\text { ended text }\end{array}$ & & & \\
\hline & \multirow[t]{5}{*}{$\begin{array}{l}\text { Teacher } \\
\text { planning }\end{array}$} & & \multirow[t]{5}{*}{$\begin{array}{l}\text { The teacher plans } \\
\text { adequately for } \\
\text { lessons }\end{array}$} & $\mathrm{Q} 4.2$ & $\begin{array}{l}\text { Do you use lesson } \\
\text { plans for teaching } \\
\text { home language? }\end{array}$ & $\begin{array}{l}\text { Polar } \\
\text { (yes/no) }\end{array}$ & & & \\
\hline & & & & Q4.3 & $\begin{array}{l}\text { Do you use lesson } \\
\text { plans for teaching } \\
\text { EFAL? }\end{array}$ & $\begin{array}{l}\text { Polar } \\
\text { (yes/no) }\end{array}$ & & & \\
\hline & & & & Q4.4 & $\begin{array}{l}\text { Where do you } \\
\text { receive your lesson } \\
\text { plans? }\end{array}$ & $\begin{array}{l}\text { Capacity } \\
\text { rating }\end{array}$ & & & \\
\hline & & & & $\begin{array}{l}\text { Relevant if grade } \\
\text { specific }\end{array}$ & $\begin{array}{l}\text { What did you teach } \\
\text { last week? }\end{array}$ & Open text & & & \\
\hline & & & & $\begin{array}{l}\text { Relevant if grade } \\
\text { specific or } \\
\text { individual teacher } \\
\text { indicator } \$\end{array}$ & $\begin{array}{l}\text { How well does the } \\
\text { teacher plan for } \\
\text { lessons? }\end{array}$ & $\begin{array}{l}\text { Capacity } \\
\text { rating }\end{array}$ & & & \\
\hline & Timetable & & $\begin{array}{l}\text { Teaching and } \\
\text { learning time has } \\
\text { been accurately } \\
\text { timetabled }\end{array}$ & Q2.2 & $\begin{array}{l}\text { On average, how } \\
\text { many hours per } \\
\text { week do you spend } \\
\text { on each of the } \\
\text { following } \\
\text { non-teaching tasks? }\end{array}$ & $\begin{array}{l}\text { Number } \\
\text { per option }\end{array}$ & & & \\
\hline & $\begin{array}{l}\text { Learner } \\
\text { homework }\end{array}$ & & $\begin{array}{l}\text { Learner } \\
\text { homework books } \\
\text { are completed }\end{array}$ & NA & $\begin{array}{l}\text { Is homework given } \\
\text { to the learners? } \\
\text { Are learners } \\
\text { compliant in } \\
\text { completing the } \\
\text { homework books? } \\
\text { Is feedback given } \\
\text { on homework? } \\
\text { Is there parental } \\
\text { compliance? }\end{array}$ & Number & & & \\
\hline
\end{tabular}


TABLE A1 (Continues...): School functionality validation matrix.

Purpose of school functionality assessment: Understand and identify school functionality status to inform school functionality improvements and identify likelihood of intervention success/relevance

\begin{tabular}{|c|c|c|c|c|c|c|c|c|c|}
\hline $\begin{array}{l}\text { School } \\
\text { functionality } \\
\text { domain }\end{array}$ & $\begin{array}{l}\text { School } \\
\text { functionality } \\
\text { category/ } \\
\text { element }\end{array}$ & $\begin{array}{l}\text { Assessment } \\
\text { objective: } \\
\text { What is being } \\
\text { measured? }\end{array}$ & $\begin{array}{l}\text { Functionality } \\
\text { variable }\end{array}$ & $\begin{array}{l}\text { Question number } \\
\text { on school } \\
\text { functionality tool } \\
\text { (for AEJ article } \\
\text { analysis) })\end{array}$ & $\begin{array}{l}\text { Question to be } \\
\text { answered }\end{array}$ & $\begin{array}{l}\text { Type of } \\
\text { data / } \\
\text { question }\end{array}$ & Research & $\begin{array}{l}\text { Norms and } \\
\text { standards: } \\
\text { Public schools } \\
\text { in SA }\end{array}$ & $\begin{array}{l}\text { Norms and } \\
\text { Standards: ECD }\end{array}$ \\
\hline \multirow[t]{15}{*}{$\begin{array}{l}\text { 3. Contextual } \\
\text { and school } \\
\text { environment }\end{array}$} & $\begin{array}{l}\text { Food and } \\
\text { Nutrition }\end{array}$ & $\begin{array}{l}\text { Learners have } \\
\text { required } \\
\text { nutrition for } \\
\text { their } \\
\text { development } \\
\text { and } \\
\text { participation in } \\
\text { learning } \\
\text { activities }\end{array}$ & $\begin{array}{l}\text { Existence and } \\
\text { effectiveness of } \\
\text { feeding scheme }\end{array}$ & $\begin{array}{l}\text { Q6.2 (Principal } \\
\text { Questionnaire) } \\
\text { Q1.2 (School } \\
\text { Functionality Tool) } \\
\text { Q1.6 (School } \\
\text { Functionality Tool) }\end{array}$ & $\begin{array}{l}\text { Does the school } \\
\text { have a feeding } \\
\text { scheme? } \\
\text { Which grades } \\
\text { receive food? } \\
\text { Is the food } \\
\text { preparation area } \\
\text { accessible and } \\
\text { available for } \\
\text { observation? } \\
\text { Is there a food } \\
\text { garden at the } \\
\text { school? } \\
\text { Is the food } \\
\text { preparation area } \\
\text { clean? }\end{array}$ & $\begin{array}{l}\text { Polar } \\
\text { (yes/no) }\end{array}$ & $\begin{array}{l}\text { Ngure et al. } \\
\text { (2014) } \\
\text { Hui Liu and } \\
\text { Stein (2013) } \\
\text { Progress for } \\
\text { Children: A } \\
\text { Report Card on } \\
\text { Nutrition, } \\
\text { UNICEF (2006) }\end{array}$ & - & $\begin{array}{l}\text { 6.1.5 Premises } \\
\text { and equipment } \\
\text { (p. 45) }\end{array}$ \\
\hline & & & & Q1.3 & $\begin{array}{l}\text { If yes, which meals } \\
\text { are provided? }\end{array}$ & $\begin{array}{l}\text { Selected } \\
\text { options }\end{array}$ & & & $\begin{array}{l}6.2 .12 \text { meals } \\
\text { and snacks } \\
\text { meeting the } \\
\text { nutritional } \\
\text { requirements }\end{array}$ \\
\hline & & & & Q1.1 & $\begin{array}{l}\text { Do the children } \\
\text { receive food at the } \\
\text { school? }\end{array}$ & $\begin{array}{l}\text { Polar } \\
\text { (yes/no) }\end{array}$ & & & $\begin{array}{l}\text { 6.1.5 Premises } \\
\text { and equipment } \\
\text { (p. 45) }\end{array}$ \\
\hline & & & & $\begin{array}{l}\text { All sample schools } \\
\text { in lower Quintiles }\end{array}$ & $\begin{array}{l}\text { If no, Is a feeding } \\
\text { scheme required? }\end{array}$ & $\begin{array}{l}\text { Polar } \\
\text { (yes/no) }\end{array}$ & & & \\
\hline & $\begin{array}{l}\text { School } \\
\text { environment }\end{array}$ & $\begin{array}{l}\text { Learning and } \\
\text { teaching is } \\
\text { provided in a } \\
\text { safe and secure } \\
\text { environment }\end{array}$ & $\begin{array}{l}\text { The learning } \\
\text { environment is } \\
\text { safe and secure }\end{array}$ & $\begin{array}{l}\text { Q3.1 } \\
\text { Q3.2 } \\
\text { Q3.5 }\end{array}$ & $\begin{array}{l}\text { Is the school } \\
\text { periphery secured? } \\
\text { Rate the safety of } \\
\text { the school } \\
\text { environment } \\
\text { Is the school area } \\
\text { clean? }\end{array}$ & $\begin{array}{l}\text { Polar } \\
\text { (yes/no) }\end{array}$ & $\begin{array}{l}\text { DBE (2008) } \\
\text { Heneveld and } \\
\text { Craig (1996) } \\
\text { Gallie (2008) }\end{array}$ & $\begin{array}{l}17 \text { perimeter } \\
\text { security and } \\
\text { school safety }\end{array}$ & $\begin{array}{l}\text { 6.1.1 Premises } \\
\text { and equipment } \\
\text { (p. 45) }\end{array}$ \\
\hline & $\begin{array}{l}\text { Learner } \\
\text { enrolment } \\
\text { and } \\
\text { attendance }\end{array}$ & $\begin{array}{l}\text { Absentee rates } \\
\text { of learners }\end{array}$ & $\begin{array}{l}\text { Absentee rate of } \\
\text { learners }\end{array}$ & Q2.1.1 & $\begin{array}{l}\text { In your current class, } \\
\text { (i) how many } \\
\text { learners should be in } \\
\text { your class every day? }\end{array}$ & Number & & 9.2 Classrooms & - \\
\hline & & & & Q2.1.2 & $\begin{array}{l}\text { For the previous full } \\
\text { week, how many } \\
\text { learners were } \\
\text { absent on average } \\
\text { every day? }\end{array}$ & Number & & & \\
\hline & & & & $\begin{array}{l}\text { Q4.1 } \\
\text { (IV) }\end{array}$ & $\begin{array}{l}\text { How much do the } \\
\text { following factors } \\
\text { affect your capacity } \\
\text { to provide good } \\
\text { language teaching } \\
\text { and learning? } \\
\text { (iv) Learner } \\
\text { absenteeism / } \\
\text { late-coming }\end{array}$ & Rating scale & & & \\
\hline & & $\begin{array}{l}\text { Access to } \\
\text { education } \\
\text { (Learner } \\
\text { enrolment) }\end{array}$ & $\begin{array}{l}\text { What percentage } \\
\text { of learners reside } \\
>10 \mathrm{~km} \text { from } \\
\text { school? }\end{array}$ & Q11 Q13 & $\begin{array}{l}\text { How long does it } \\
\text { take your child to } \\
\text { get to school? } \\
\text { Is your child's } \\
\text { school the nearest } \\
\text { school to where } \\
\text { you live? Distance } \\
\text { between learners } \\
\text { reside and school? }\end{array}$ & $\begin{array}{l}\text { Time } \\
\text { Polar (yes/ } \\
\text { no) } \\
\text { Percentage }\end{array}$ & $\begin{array}{l}\text { De Kadt et al. } \\
\text { (2014) }\end{array}$ & - & - \\
\hline & & & $\begin{array}{l}\text { Enrolment } \\
\text { Pyramid (\% } \\
\text { change as } \\
\text { applicable by } \\
\text { school type) }\end{array}$ & NA & & Percentage & & & \\
\hline & $\begin{array}{l}\text { Health and } \\
\text { hygiene }\end{array}$ & $\begin{array}{l}\text { Provision of } \\
\text { water, } \\
\text { sanitation and } \\
\text { hygiene }\end{array}$ & $\begin{array}{l}\text { The school } \\
\text { provides } \\
\text { adequate, safe } \\
\text { and clean water, } \\
\text { sanitation and } \\
\text { hygiene for } \\
\text { learners }\end{array}$ & $\begin{array}{l}\text { Q2.6 } \\
\text { Q2.4 } \\
\text { Q2.5 }\end{array}$ & $\begin{array}{l}\text { Are these sanitation } \\
\text { facilities safe? } \\
\text { Are these sanitation } \\
\text { facilities safe? } \\
\text { Are the learners' } \\
\text { sanitation facilities } \\
\text { clean? }\end{array}$ & $\begin{array}{l}\text { Capacity } \\
\text { rating }\end{array}$ & $\begin{array}{l}\text { Spaull (2012) } \\
\text { Kisoon (2019) } \\
\text { SAHRC (2014) }\end{array}$ & 12.1 Sanitation & $\begin{array}{l}\text { 6.1.7 Premises } \\
\text { and equipment }\end{array}$ \\
\hline & & & & Analysed & $\begin{array}{l}\text { Does the ratio of } \\
\text { learners to toilets } \\
\text { exceed } 1: 40 \text { ? }\end{array}$ & Ratio & & $\begin{array}{l}\text { 9.2.b } \\
\text { Classrooms }\end{array}$ & $\begin{array}{l}\text { 6.1.7 Premises } \\
\text { and equipment }\end{array}$ \\
\hline & & & & Q3.5 & $\begin{array}{l}\text { Are the school } \\
\text { grounds/area } \\
\text { clean? }\end{array}$ & $\begin{array}{l}\text { Capacity } \\
\text { rating }\end{array}$ & & - & $\begin{array}{l}6.2 .10 \text { healthy } \\
\text { environment } \\
\text { for children } \\
\text { and staff }\end{array}$ \\
\hline & & & & Q2.7 & $\begin{array}{l}\text { Are there hand } \\
\text { washing facilities? }\end{array}$ & $\begin{array}{l}\text { Capacity } \\
\text { rating }\end{array}$ & & 12.1 Sanitation & $\begin{array}{l}\text { 6.1.7 Premises } \\
\text { and equipment }\end{array}$ \\
\hline & & & & Q2.9 & $\begin{array}{l}\text { Is clean drinking } \\
\text { water provided? }\end{array}$ & $\begin{array}{l}\text { Capacity } \\
\text { rating }\end{array}$ & & 11.1 Water & $\begin{array}{l}\text { 6.1.7 Premises } \\
\text { and equipment }\end{array}$ \\
\hline
\end{tabular}

Table A1 continues on the next page $\rightarrow$ 
TABLE A1 (Continues...): School functionality validation matrix.

Purpose of school functionality assessment: Understand and identify school functionality status to inform school functionality improvements and identify likelihood of intervention success/relevance

\begin{tabular}{|c|c|c|c|c|c|c|c|c|c|}
\hline $\begin{array}{l}\text { School } \\
\text { functionality } \\
\text { domain }\end{array}$ & $\begin{array}{l}\text { School } \\
\text { functionality } \\
\text { category/ } \\
\text { element }\end{array}$ & $\begin{array}{l}\text { Assessment } \\
\text { objective: } \\
\text { What is being } \\
\text { measured? }\end{array}$ & $\begin{array}{l}\text { Functionality } \\
\text { variable }\end{array}$ & $\begin{array}{l}\text { Question number } \\
\text { on school } \\
\text { functionality tool } \\
\text { (for AEJ article } \\
\text { analysis) } \$\end{array}$ & $\begin{array}{l}\text { Question to be } \\
\text { answered }\end{array}$ & $\begin{array}{l}\text { Type of } \\
\text { data / } \\
\text { question }\end{array}$ & Research & $\begin{array}{l}\text { Norms and } \\
\text { standards: } \\
\text { Public schools } \\
\text { in SA }\end{array}$ & $\begin{array}{l}\text { Norms and } \\
\text { Standards: ECD }\end{array}$ \\
\hline & $\begin{array}{l}\text { Educator } \\
\text { quality and } \\
\text { quantity }\end{array}$ & $\begin{array}{l}\text { Educators } \\
\text { provision }\end{array}$ & $\begin{array}{l}\text { Percent educators } \\
\text { late (day of } \\
\text { school visit) }\end{array}$ & NA & - & Percentage & $\begin{array}{l}\text { Taylor (2011) } \\
\text { Spaull (2012) }\end{array}$ & - & - \\
\hline & & & $\begin{array}{l}\text { Learners per } \\
\text { classroom }\end{array}$ & Q2.4-Q2.6 & $\begin{array}{l}\text { How many learners } \\
\text { are enrolled per } \\
\text { grade? } \\
\text { †How many grade } 1 \\
\text { learners are } \\
\text { enrolled at your } \\
\text { school this year? } \\
\text { †How many grade } 3 \\
\text { learners are } \\
\text { enrolled at your } \\
\text { school this year? } \\
\text { †How many grade } 4 \\
\text { learners are } \\
\text { enrolled at your } \\
\text { school this year? }\end{array}$ & Number & & $\begin{array}{l}9 \text { (b) Maximum } \\
\text { of } 40 \text { learners }\end{array}$ & $\begin{array}{l}9 \text { (a) Maximum } \\
\text { of } 30 \text { learners } \\
\text { per class }\end{array}$ \\
\hline & & & $\begin{array}{l}\text { Learners per } \\
\text { educator }\end{array}$ & - & $\begin{array}{l}\text { (Analysed from } \\
\text { question 2) }\end{array}$ & Ratio & & - & - \\
\hline & & & $\begin{array}{l}\text { Educator } \\
\text { vacancies }\end{array}$ & Q2.7 & $\begin{array}{l}\text { How many } \\
\text { educators are there } \\
\text { per grade? }\end{array}$ & Number & - & - & - \\
\hline & $\begin{array}{l}\text { District } \\
\text { Support }\end{array}$ & $\begin{array}{l}\text { Effective } \\
\text { support from } \\
\text { education } \\
\text { system }\end{array}$ & $\begin{array}{l}\text { District resources, } \\
\text { support, systems, } \\
\text { monitoring and } \\
\text { professional } \\
\text { development }\end{array}$ & NAt & - & - & $\begin{array}{l}\text { JET (2010) } \\
\text { Heneveld and } \\
\text { Craig (1996) }\end{array}$ & 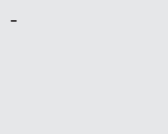 & - \\
\hline \multirow[t]{6}{*}{$\begin{array}{l}\text { 4. Resources } \\
\text { and } \\
\text { materials }\end{array}$} & $\begin{array}{l}\text { School } \\
\text { Infrastructure }\end{array}$ & $\begin{array}{l}\text { Adequate } \\
\text { facilities }\end{array}$ & $\begin{array}{l}\text { Adequate } \\
\text { classrooms } \\
\text { provided for } \\
\text { learners }\end{array}$ & $\begin{array}{l}\text { Q4.1 } \\
\text { (V) }\end{array}$ & $\begin{array}{l}\text { How much do the } \\
\text { following factors } \\
\text { affect your capacity } \\
\text { to teach: } \\
\text { [Inadequate } \\
\text { workspace / too } \\
\text { many learners in } \\
\text { the classroom] }\end{array}$ & Rating scale & \multirow[t]{4}{*}{-} & \multirow{4}{*}{$\begin{array}{l}\text { 7. Site and } \\
\text { identification } \\
\text { of school } \\
8 \text {. Categories } \\
\text { of key school } \\
\text { areas and their } \\
\text { sizes } \\
\text { 9. Classrooms } \\
\text { 15. Sport and } \\
\text { recreation } \\
\text { facilities }\end{array}$} & $\begin{array}{l}\text { 6.1.7 Premises } \\
\text { and equipment }\end{array}$ \\
\hline & & & $\begin{array}{l}\text { Adequate } \\
\text { facilities for } \\
\text { quality teaching } \\
\text { and learning }\end{array}$ & NA & $\begin{array}{l}\text { Is there a school } \\
\text { hall? } \\
\text { Please rate the } \\
\text { functionality of the } \\
\text { hall }\end{array}$ & $\begin{array}{l}\text { Polar } \\
\text { (yes/no) } \\
\text { Rating scale }\end{array}$ & & & $\begin{array}{l}6.1 .10 \\
\text { Premises and } \\
\text { equipment }\end{array}$ \\
\hline & & & $\begin{array}{l}\text { Adequate space } \\
\text { for learners to } \\
\text { play }\end{array}$ & Q3.3 & $\begin{array}{l}\text { Is there an } \\
\text { adequate outside } \\
\text { playing area? } \\
\text { Are there sports } \\
\text { grounds? }\end{array}$ & $\begin{array}{l}\text { Capacity } \\
\text { rating }\end{array}$ & & & $\begin{array}{l}6.1 .2 \\
\text { playroom, } \\
\text { office and } \\
\text { kitchen clearly } \\
\text { marked }\end{array}$ \\
\hline & & & $\begin{array}{l}\text { Ratio of learners } \\
\text { per computer }\end{array}$ & NA & - & Ratio & & & - \\
\hline & Fee schedules & $\begin{array}{l}\text { Fee payment } \\
\text { schedules }\end{array}$ & $\begin{array}{l}\text { If fees are } \\
\text { charged, what } \\
\text { per cent of } \\
\text { learners are fully } \\
\text { or partially } \\
\text { exempt from } \\
\text { fees? }\end{array}$ & $\begin{array}{l}\text { NA All quintile 1-3 } \\
\text { schools }\end{array}$ & - & Percentage & - & - & - \\
\hline & $\begin{array}{l}\text { Teaching and } \\
\text { learning } \\
\text { materials }\end{array}$ & $\begin{array}{l}\text { Learner } \\
\text { Materials }\end{array}$ & $\begin{array}{l}\text { Availability of } \\
\text { teaching and } \\
\text { learning materials }\end{array}$ & Q1.1 & $\begin{array}{l}\text { Classroom } \\
\text { observation. (a) } \\
\text { Rate the existence, } \\
\text { sufficiency and } \\
\text { quality of the } \\
\text { classroom } \\
\text { infrastructure, } \\
\text { facilities and } \\
\text { materials as } \\
\text { indicated in the } \\
\text { table }\end{array}$ & $\begin{array}{l}\text { Capacity } \\
\text { rating }\end{array}$ & $\begin{array}{l}\text { Haneveld and } \\
\text { Craig (1996) } \\
\text { Gallie (2008) } \\
\text { Sasol Inzalo } \\
\text { (2009) JET } \\
\text { (2010) Khulisa } \\
\text { (2012) }\end{array}$ & - & $\begin{array}{l}\text { 6.1.10 There } \\
\text { must be } \\
\text { enough age } \\
\text { appropriate } \\
\text { indoor as well } \\
\text { as outdoor play } \\
\text { equipment and } \\
\text { toys, books } \\
\text { and print } \\
\text { material and } \\
\text { other materials }\end{array}$ \\
\hline
\end{tabular}


TABLE A1 (Continues...): School functionality validation matrix.

Purpose of school functionality assessment: Understand and identify school functionality status to inform school functionality improvements and identify likelihood of intervention success/relevance

\begin{tabular}{|c|c|c|c|c|c|c|c|c|c|}
\hline $\begin{array}{l}\text { School } \\
\text { functionality } \\
\text { domain }\end{array}$ & $\begin{array}{l}\text { School } \\
\text { functionality } \\
\text { category/ } \\
\text { element }\end{array}$ & $\begin{array}{l}\text { Assessment } \\
\text { objective: } \\
\text { What is being } \\
\text { measured? }\end{array}$ & $\begin{array}{l}\text { Functionality } \\
\text { variable }\end{array}$ & $\begin{array}{l}\text { Question number } \\
\text { on school } \\
\text { functionality tool } \\
\text { (for AEJ article } \\
\text { analysis) } \$\end{array}$ & $\begin{array}{l}\text { Question to be } \\
\text { answered }\end{array}$ & $\begin{array}{l}\text { Type of } \\
\text { data / } \\
\text { question }\end{array}$ & Research & $\begin{array}{l}\text { Norms and } \\
\text { standards: } \\
\text { Public schools } \\
\text { in SA }\end{array}$ & $\begin{array}{l}\text { Norms and } \\
\text { Standards: ECD }\end{array}$ \\
\hline & - & - & - & $\begin{array}{l}\mathrm{Q} 4.1(\mathrm{I})(\mathrm{II}) \\
\mathrm{Q} 4.5 \mathrm{Q} 4.5 .3\end{array}$ & $\begin{array}{l}\text { How much do the } \\
\text { following factors } \\
\text { affect your capacity } \\
\text { to provide good } \\
\text { language teaching } \\
\text { and learning? } \\
\text { (i) Shortages of } \\
\text { language } \\
\text { workbooks for } \\
\text { every learner } \\
\text { (ii) Shortages of } \\
\text { readers (or library } \\
\text { books) for every } \\
\text { learner } \\
\text { Do you have the } \\
\text { [project specific] } \\
\text { books in your } \\
\text { classroom? } \\
\text { Do you have any } \\
\text { other graded } \\
\text { readers in your } \\
\text { classroom? }\end{array}$ & Rating scale & - & - & - \\
\hline & - & $\begin{array}{l}\text { EGRS teaching } \\
\text { and learning } \\
\text { materials }\end{array}$ & $\begin{array}{l}\text { Access and } \\
\text { utilisation of } \\
\text { teaching and } \\
\text { learning } \\
\text { resources }\end{array}$ & Q5.1 & $\begin{array}{l}\text { Are the teaching } \\
\text { and learning } \\
\text { materials accessible } \\
\text { and being used? }\end{array}$ & Rating scale & - & - & - \\
\hline & - & $\begin{array}{l}\text { Access and use } \\
\text { of reading } \\
\text { material }\end{array}$ & $\begin{array}{l}\text { School } \\
\text { libraryClassroom } \\
\text { reading corner }\end{array}$ & $\begin{array}{l}\text { Q3.6 } \\
\text { Q3.7 } \\
\text { Q3.8 }\end{array}$ & $\begin{array}{l}\text { Does the school } \\
\text { have a library/ } \\
\text { multi-media } \\
\text { centre? } \\
\text { Rate the } \\
\text { functionality of the } \\
\text { library/multi-media } \\
\text { centre (resources } \\
\text { and cleanliness) }\end{array}$ & $\begin{array}{l}\text { Capacity } \\
\text { rating }\end{array}$ & $\begin{array}{l}\text { Refer to Khulisa } \\
\text { RSP Literature } \\
\text { Review } 2019\end{array}$ & 13.1 Library & - \\
\hline & - & & $\begin{array}{l}\text { School library } \\
\text { Classroom } \\
\text { reading corner }\end{array}$ & $\begin{array}{l}\text { Q3.6 } \\
\text { Q3.7 } \\
\text { Q3.8 } \\
\text { Q1.1 (I-XI) }\end{array}$ & $\begin{array}{l}\text { Does the school } \\
\text { have a library? } \\
\text { Rate the } \\
\text { functionality of the } \\
\text { library/multi-media } \\
\text { centre (resources } \\
\text { and cleanliness) } \\
\text { Rate the existence, } \\
\text { sufficiency and } \\
\text { quality of: reading } \\
\text { corner, story books, } \\
\text { wall charts, posters } \\
\text { and flash cards }\end{array}$ & $\begin{array}{l}\text { Capacity } \\
\text { rating }\end{array}$ & & 13.1 Library & \\
\hline & - & - & $\begin{array}{l}\text { Reservoir of } \\
\text { cognitive and } \\
\text { other resources } \\
\text { available to the } \\
\text { school }\end{array}$ & NA & - & $\begin{array}{l}\text { Analysis } \\
\text { across } \\
\text { range of } \\
\text { variables }\end{array}$ & $\begin{array}{l}\text { Görgens- } \\
\text { Ekermans, } \\
\text { Delport \& Du } \\
\text { Preez (2015) }\end{array}$ & - & - \\
\hline & - & $\begin{array}{l}\text { Development } \\
\text { of broad range } \\
\text { of learner } \\
\text { competencies }\end{array}$ & $\begin{array}{l}\text { Range of } \\
\text { extra-curricular } \\
\text { activities } \\
\text { provided }\end{array}$ & NA & $\begin{array}{l}\text { Holistic } \\
\text { development of } \\
\text { child }\end{array}$ & $\begin{array}{l}\text { Capacity of } \\
\text { school to } \\
\text { provide } \\
\text { (rating) }\end{array}$ & - & - & - \\
\hline & $\begin{array}{l}\text { Social } \\
\text { development, } \\
\text { support \& } \\
\text { wellbeing }\end{array}$ & $\begin{array}{l}\text { Provision of } \\
\text { social support } \\
\text { to learners (is } \\
\text { balanced with }\end{array}$ & $\begin{array}{l}\text { Learners are } \\
\text { supported } \\
\text { through social } \\
\text { grants }\end{array}$ & NA & $\begin{array}{l}\text { Does the school } \\
\text { track social grants? }\end{array}$ & $\begin{array}{l}\text { Polar (yes/ } \\
\text { no) }\end{array}$ & $\begin{array}{l}\text { Ebersöhn et al. } \\
\text { (2015) }\end{array}$ & - & - \\
\hline & & $\begin{array}{l}\text { educational } \\
\text { outcomes) }\end{array}$ & $\begin{array}{l}\text { Learner's access } \\
\text { to additional } \\
\text { support } \\
\text { (secondary } \\
\text { support) }\end{array}$ & Q6.3 & $\begin{array}{l}\text { Does the school } \\
\text { have a referral } \\
\text { network?Does the } \\
\text { school have } \\
\text { emergency } \\
\text { numbers and } \\
\text { procedures } \\
\text { displayed? } \\
\text { Does the school } \\
\text { have a referral } \\
\text { network or circle of } \\
\text { support? }\end{array}$ & $\begin{array}{l}\text { Capacity } \\
\text { rating }\end{array}$ & & - & $\begin{array}{l}6.2 .4 \text { plans to } \\
\text { deal with } \\
\text { emergencies }\end{array}$ \\
\hline & & & $\begin{array}{l}\text { Learner access to } \\
\text { social worker }\end{array}$ & NA & $\begin{array}{l}\text { Does the school } \\
\text { have an in-house or } \\
\text { external social } \\
\text { worker? }\end{array}$ & $\begin{array}{l}\text { Polar (yes/ } \\
\text { no) }\end{array}$ & & - & $\begin{array}{l}6.2 .6 \text { Staff } \\
\text { should be } \\
\text { trained to } \\
\text { recognise early } \\
\text { signs of child } \\
\text { abuse and how } \\
\text { to protect } \\
\text { children } \\
\text { (contacting of } \\
\text { social worker) }\end{array}$ \\
\hline
\end{tabular}


TABLE A1 (Continues...): School functionality validation matrix.

Purpose of school functionality assessment: Understand and identify school functionality status to inform school functionality improvements and identify likelihood of intervention success/relevance

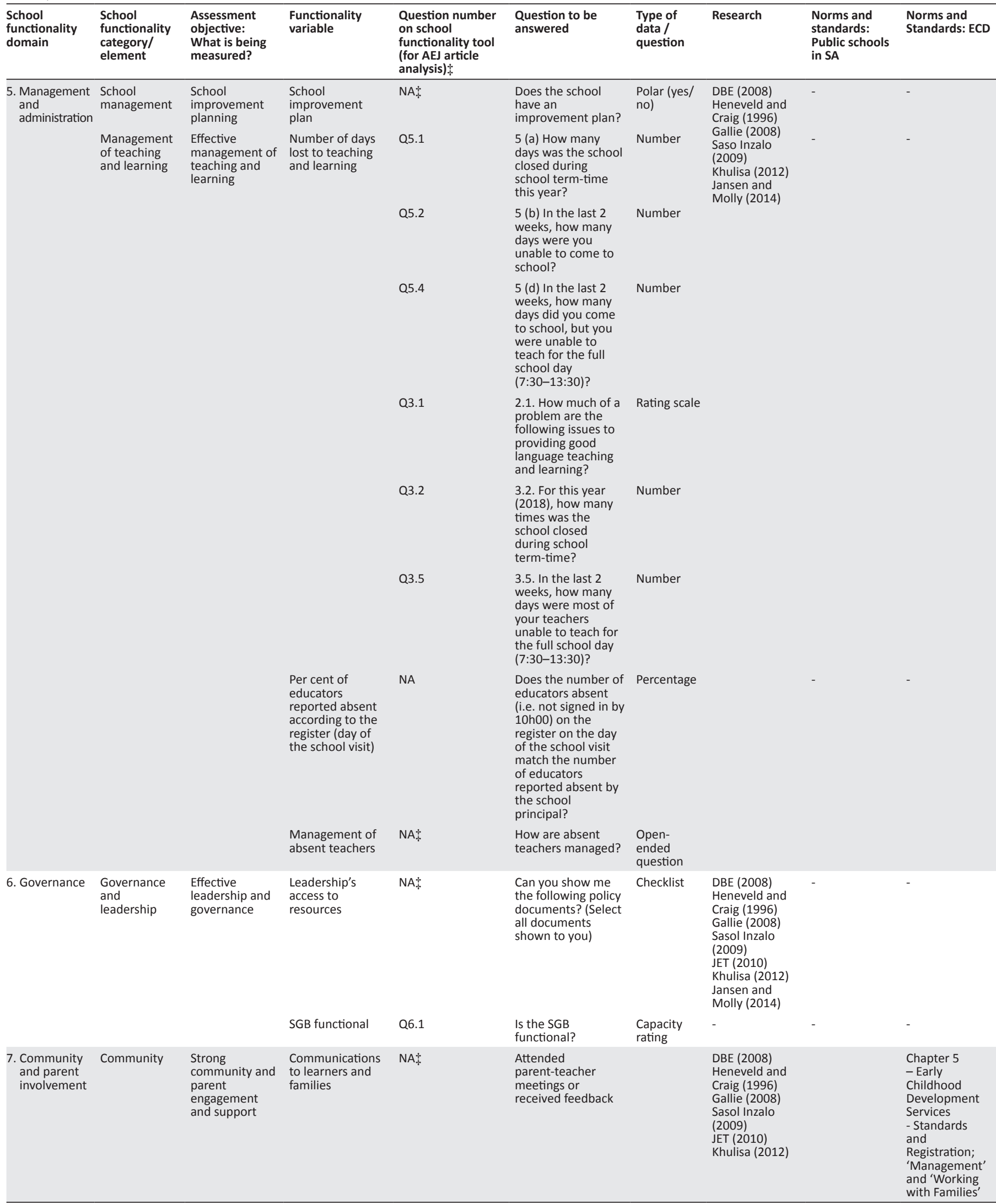


TABLE A1 (Continues...): School functionality validation matrix.

Purpose of school functionality assessment: Understand and identify school functionality status to inform school functionality improvements and identify likelihood of intervention success/relevance

\begin{tabular}{|c|c|c|c|c|c|c|c|c|c|}
\hline $\begin{array}{l}\text { School } \\
\text { functionality } \\
\text { domain }\end{array}$ & $\begin{array}{l}\text { School } \\
\text { functionality } \\
\text { category/ } \\
\text { element }\end{array}$ & $\begin{array}{l}\text { Assessment } \\
\text { objective: } \\
\text { What is being } \\
\text { measured? }\end{array}$ & $\begin{array}{l}\text { Functionality } \\
\text { variable }\end{array}$ & $\begin{array}{l}\text { Question number } \\
\text { on school } \\
\text { functionality tool } \\
\text { (for AEJ article } \\
\text { analysis) } \$\end{array}$ & $\begin{array}{l}\text { Question to be } \\
\text { answered }\end{array}$ & $\begin{array}{l}\text { Type of } \\
\text { data / } \\
\text { question }\end{array}$ & Research & $\begin{array}{l}\text { Norms and } \\
\text { standards: } \\
\text { Public schools } \\
\text { in SA }\end{array}$ & $\begin{array}{l}\text { Norms and } \\
\text { Standards: ECD }\end{array}$ \\
\hline \multirow[t]{6}{*}{$\begin{array}{l}\text { 8. Professional } \\
\text { development } \\
\text { of educators }\end{array}$} & $\begin{array}{l}\text { Professional } \\
\text { development } \\
\text { of educators }\end{array}$ & - & $\begin{array}{l}\text { Status of } \\
\text { educator's PLCs in } \\
\text { IQMS } \\
\text { Professional } \\
\text { Learning } \\
\text { Community (PLC) }\end{array}$ & NA $\doteqdot$ & - & $\begin{array}{l}\text { Rating scale } \\
\text { (status) }\end{array}$ & $\begin{array}{l}\text { DBE (2008)JET } \\
(2010) \text { Sasol } \\
\text { Inzalo (2009) } \\
\text { Khulisa (2012) }\end{array}$ & - & $\begin{array}{l}6.5 \\
\text { Practitioners } \\
\text { and Appendix } \\
\text { 4: NQF Levels } 1 \\
\text { and } 4 \text { ECD } \\
\text { Qualifications }\end{array}$ \\
\hline & & & $\begin{array}{l}\text { Educator training: } \\
\text { Availability and } \\
\text { desire }\end{array}$ & Q6.1 & $\begin{array}{l}6(a) \text { In [year], did } \\
\text { you received } \\
\text { professional } \\
\text { in-service teacher } \\
\text { training on how to } \\
\text { teach Setswana as } \\
\text { home language? }\end{array}$ & $\begin{array}{l}\text { Polar } \\
\text { (yes/no) }\end{array}$ & & & \\
\hline & & & & Q6.2 & $\begin{array}{l}6(\mathrm{~b}) \text { In this year } \\
\text { [year], have you } \\
\text { received } \\
\text { professional } \\
\text { in-service teacher } \\
\text { training on how to } \\
\text { teach Setswana as } \\
\text { home language? }\end{array}$ & $\begin{array}{l}\text { Polar } \\
\text { (yes/no) }\end{array}$ & & & \\
\hline & & & & Q6.3 & $\begin{array}{l}6 \text { (c) In the previous } \\
\text { year [year], did you } \\
\text { received } \\
\text { professional } \\
\text { in-service teacher } \\
\text { training on how to } \\
\text { teach English as } \\
\text { First Additional } \\
\text { Language (EFAL)? }\end{array}$ & $\begin{array}{l}\text { Polar } \\
\text { (yes/no) }\end{array}$ & & & \\
\hline & & & & Q6.4 & $\begin{array}{l}6(\mathrm{~d}) \text { In this year } \\
\text { [year], have you } \\
\text { received } \\
\text { professional } \\
\text { in-service teacher } \\
\text { training on how to } \\
\text { teach English as } \\
\text { First Additional } \\
\text { Language (EFAL)? }\end{array}$ & $\begin{array}{l}\text { Polar } \\
\text { (yes/no) }\end{array}$ & & & \\
\hline & & & & Q6.5 (i) & $\begin{array}{l}6 \text { (e) How strongly } \\
\text { do you agree with } \\
\text { the following } \\
\text { statements [insert } \\
\text { feeling supported } \\
\text { statements in tool]? }\end{array}$ & Likert scale & & & \\
\hline $\begin{array}{l}\text { 9. Addressing } \\
\text { learner } \\
\text { barriers }\end{array}$ & $\begin{array}{l}\text { Inclusive } \\
\text { education }\end{array}$ & $\begin{array}{l}\text { Inclusive } \\
\text { education }\end{array}$ & $\begin{array}{l}\text { Extent school/ } \\
\text { teacher provides } \\
\text { an inclusive } \\
\text { education } \\
\text { environment or } \\
\text { activities }\end{array}$ & NAt! & $\begin{array}{l}\text { How are teachers } \\
\text { addressing learner } \\
\text { barriers? } \\
\text { To what extent is } \\
\text { inclusive education } \\
\text { addressed? }\end{array}$ & - & $\begin{array}{l}\text { Khulisa (2017) } \\
\text { Heneveld and } \\
\text { Craig (1996) }\end{array}$ & - & $\begin{array}{l}6.5 \\
\text { Practitioners } \\
\text { and } \\
7 . \\
\text { Infrastructure }\end{array}$ \\
\hline $\begin{array}{l}\text { Rating of } \\
\text { school } \\
\text { functionality }\end{array}$ & - & $\begin{array}{l}\text { To what extent } \\
\text { is the school } \\
\text { functional? }\end{array}$ & $\begin{array}{l}\text { School is rated: } \\
\text { (1) Highly } \\
\text { functional } \\
\text { (2) Stagnant, but } \\
\text { functional } \\
\text { (3) Functional } \\
\text { (4) Dysfunctional }\end{array}$ & Q7.2 & $\begin{array}{l}\text { Standard setting } \\
\text { question for } \\
\text { researcher } \\
\text { observation: Would } \\
\text { I send my child to } \\
\text { this school? }\end{array}$ & $\begin{array}{l}\text { Capacity } \\
\text { rating }\end{array}$ & - & - & - \\
\hline
\end{tabular}

ECD, early childhood development; CAPS, Curriculum and Policy Statements; SGB, school governing body; IQMS, Integrated Quality Management System; NA, not applicable; PLC, professional learning community.

$\dagger$, Not applicable (NA): Questions were asked in the additional evaluation instruments for this evaluation, and many were included in earlier versions of the tool and therefore not included in this school functionality tool; $\$$, Not applicable (NA): Questions were asked in the additional evaluation instruments for this evaluation, and many were included in earlier versions of the tool and therefore not included in this school functionality tool. 